\title{
Antibacterial and antibiotic-resistance modifying activity of the extracts and compounds from Nauclea pobeguinii against Gram-negative multi-drug resistant phenotypes
}

\author{
Jackson A. Seukep ${ }^{1}$, Louis P. Sandjo², Bonaventure T. Ngadjui ${ }^{3}$ and Victor Kuete ${ }^{1 *}$
}

\begin{abstract}
Background: Multi-drug resistance of Gram-negative bacteria constitutes a major obstacle in the antibacterial fight worldwide. The discovery of new and effective antimicrobials and/or resistance modulators is necessary to combat the spread of resistance or to reverse the multi-drug resistance. In this study, we investigated the antibacterial and antibiotic-resistance modifying activities against 29 Gram-negative bacteria including multi-drug resistant (MDR) phenotypes of the methanol extracts from Nauclea pobeguiinii leaves (NPL), Nauclea pobeguiinii bark (NPB) and six compounds from the bark extract, identified as 3-acetoxy-11-oxo-urs-12-ene (1), p-coumaric acid (2), citric acid trimethyl ester (3), resveratrol (4), resveratrol $\beta$-D-glucopyranoside (5) and strictosamide (6).

Methods: The broth microdilution method was used to determine the minimal inhibitory concentrations (MIC) and minimal bactericidal concentrations (MBC) of crude extracts and compounds as well as the antibiotic-resistance modifying effects of MPB and 4.

Results: MIC determinations indicate values ranging from 32-1024 $\mu \mathrm{g} / \mathrm{mL}$ for NPB and NPL on $89.7 \%$ and $69.0 \%$ of the tested bacterial strains respectively. MIC values below $100 \mu \mathrm{g} / \mathrm{mL}$ were obtained with NPB against Escherichia coli ATCC10536, AG100 and Enterobacter aerogenes CM64 strains. The lowest MIC value for crude extracts of $32 \mu \mathrm{g} / \mathrm{mL}$ was obtained with NPB against E. coli ATCC10536. Compound 4 was active all tested bacteria, whilst 1, 3 and 6 displayed weak and selective inhibitory effects. The corresponding MIC value $(16 \mu \mathrm{g} / \mathrm{mL})$ was obtained with 4 against Klebsiella pneumoniae KP55 strain. Synergistic effects of the combination of NPB with chloramphenicol $(\mathrm{CHL})$, kanamycin (KAN) as well as that of compound $\mathbf{4}$ with streptomycin (STR) and ciprofloxacin (CIP) were observed.
\end{abstract}

Conclusion: The present study provides information on the possible use of Nauclea pobeguinii and compound 4 in the control of Gram-negative bacterial infections including MDR phenotypes. It also indicates that NPB and 4 can be used as naturally occurring antibiotic-resistance modulators to tackle MDR bacteria.

Keywords: Antibacterial, Gram-negative bacteria, Nauclea pobeguinii, Efflux pumps, Multidrug resistant, Resveratrol

\footnotetext{
* Correspondence: kuetevictor@yahoo.fr

'Department of Biochemistry, Faculty of Science, University of Dschang,

Dschang, Cameroon

Full list of author information is available at the end of the article
}

\section{$\int$ Biomed Central}

(c) 2016 The Author(s). Open Access This article is distributed under the terms of the Creative Commons Attribution 4.0 International License (http://creativecommons.org/licenses/by/4.0/), which permits unrestricted use, distribution, and reproduction in any medium, provided you give appropriate credit to the original author(s) and the source, provide a link to the Creative Commons license, and indicate if changes were made. The Creative Commons Public Domain Dedication waiver (http://creativecommons.org/publicdomain/zero/1.0/) applies to the data made available in this article, unless otherwise stated. 


\section{Background}

Bacterial multi-drug resistance (MDR) constitutes a major impediment to antibiotherapy worldwide. Overexpression of tripartite efflux pumps of resistance-nodulation-cell division (RND) family such as AcrAB-TolC in enterobacteria or MexAB-OprM in Pseudomonas aeruginosa have been reported as one of the major mechanism of MDR in Gram-negative bacteria [1, 2]. High rates of resistance of Gram-negative bacteria to commonly used antibiotics has been previously reported in Cameroon [3]. Medically important enterobacteria overexpressing efflux pumps include various species such as Escherichia coli, Klebsiella pneumoniae, Enterobacter aerogenes, Enterobacter cloacae, Providencia stuartii, Salmonella typhi $[4,5]$. The scarcity of the development of new antibiotics propels development of alternative medicine including phytotherapy. In fact, medicinal plants represent a good source of antimicrobials, in regards to the diversity of their secondary metabolites $[6,7]$. African flora is very rich and has shown a good potential to fight various human ailments [8]. Therefore, exploring African flora for antibacterial drug discovery appears as an attractive strategy. In the past, several medicinal plants of the continent showed good antibacterial activities against MDR Gram-negative (MDRGN) bacterial species. Some of the most prominent plants include Dichrostachys glomerata, Beilschmiedia cinnamomea, Combretum molle [9, 10], Piper nigrum and Telfairia occidentalis [11], Beilschmedia acuta [12] and Dorstenia psilurus [13]. Also, several compounds isolated from African plants displayed good inhibitory effects against MDRGN. Amongst these are pomolic acid [14], neobavaisoflavone [15], plumbagin, 4-hydroxylonchocarpin [4] and $5^{\prime}$-methoxyhydnocarpin [16]. The discovery of efflux pump inhibitors (EPIs) is a good alternative to combat MDRGN [17]. EPI generally interact with specific efflux pump proteins to restore the susceptibility of MDR bacteria to antibiotics [18]. The search of EPI phytochemicals that can restore the activity of antibiotics also increase the possibilities to overcome MDR phenotypes. In the past, numbers of plants extracts and derived molecules have been able to potentiate the activity of various classes of antibiotics against MDR bacteria $[16,19-21]$. In our continuous quest of naturally occurring bioactive products to tackle bacterial multi-drug resistance, the present study was designed to evaluate the antibacterial activity of methanol extracts and compounds from Nauclea pobeguinii (Pobég. ex Pellegr.) Merr. ex E.M.A. (Rubiaceae) against a panel of 29 bacteria including MDR phenotypes. The study was extended to the evaluation of the ability of the studied samples to restore the activity of commonly used antibiotics towards MDR strains. Nauclea pobeguinii is used in traditional medicine as abortive and for the treatment of stomach ache, infectious diseases [22], jaundice [23], fever, diarrhea, worm, and malaria [24]. Recently, the plant was shown to have cytotoxic effects on various hematological and carcinoma cell lines [25]. Previous phytochemical investigation of the plant led to the isolation of compounds identified as 3-acetoxy-11-oxo-urs12-ene (1), $p$-coumaric acid (2), citric acid trimethyl ester (3), resveratrol (4), resveratrol $\beta_{-}{ }^{-}$-glucopyranoside (5) and strictosamide (6) [25]. The antimalarial efficacy of stem bark extract of Nauclea pobeguinii in human adult volunteers with diagnosed uncomplicated falciparum malaria was also reported [26].

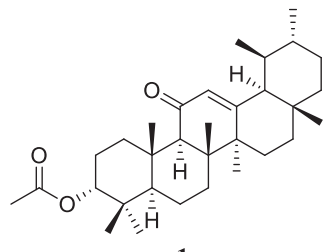

1

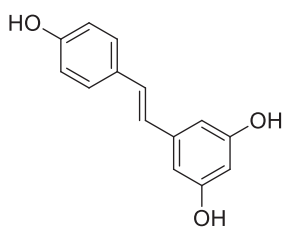

4

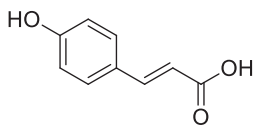

2

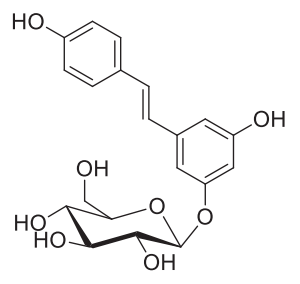

5
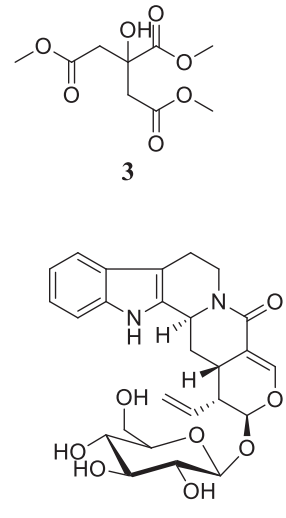

6

Fig. 1 Chemical structures of the compounds isolated from Nauclea pobeguinii. 1: 3-acetoxy-11-oxo-urs-12-ene; 2: p-coumaric acid; 3: citric acid trimethyl ester; 4: resveratrol; 5: resveratrol $\beta_{-}{ }_{-}$-glucopyranoside; $\mathbf{6}$ : strictosamide 


\section{Methods}

\section{Plant material and extraction}

The leaves and bark of Nauclea pobeguinii was collected in March and April 2013 at Mbouda (West Region of Cameroon). The plant was identified at the National Herbarium in Yaoundé, Cameroon and compared with voucher formerly kept under the registration number $32597 /$ HNC. Each plant part was air dried and then powdered. The obtained powder (200 g) was extracted with methanol $(\mathrm{MeOH} ; 1 \mathrm{~L})$ for $48 \mathrm{~h}$ at room temperature with momentary shaking. Methanol was then removed under reduced pressure to give residues which constituted the crude bark (NPB) and leaves (NPL) extracts. All extracts were then kept at $4{ }^{\circ} \mathrm{C}$ until further use.

\section{Chemicals for antimicrobial assay}

Compounds previously isolated from the bark of Nauclea pobeguinii included 3-acetoxy-11-oxo-urs-12-ene (1), p-coumaric acid (2), citric acid trimethyl ester (3), resveratrol (4), resveratrol $\beta$ - ${ }^{-}$-glucopyranoside (5) and strictosamide (6) (Fig. 1). Their isolation and identification were previously reported [25]. Tetracycline (TET), cefepime (CEP), ciprofloxacin (CIP), chloramphenicol (CHL), ampicillin (AMP), streptomycin (STR), kanamycin (KAN) (Sigma-Aldrich, St Quentin Fallavier, France) were used as reference antibiotics (RA). p-Iodonitrotetrazolium chloride (INT; Sigma-Aldrich) and PhenylalanineArginine-ß-Naphthylamide (PAßN; Sigma-Aldrich) were used as microbial growth indicator and efflux pumps inhibitor (EPI) respectively [27, 28].

\section{Microbial strains and culture media}

The studied microorganisms included sensitive and resistant strains of Escherichia coli (ATTC8739, ATCC10536, AG100, AG100A, AG102, AG100ATet, MC4100, W3110), Enterobacter aerogenes (ATCC13048, EA3, EA289, EA294, EA27, EA298, CM64), Klebsiella pneumoniae (ATCC11296, KР55, KР63, K2, K24), Pseudomonas aeruginosa (PA01, PA124), Providencia stuartii (ATCC29914, NEA16, PS299645, PS2636) and Enterobacter cloacae (BM47, BM67, ECCI69) obtained clinically or from the American Type Culture Collection (ATCC). Their resistance profiles have been previously reported (see Additional file 1: Table S1). Nutrient agar were used for the activation of the tested Gram-negative bacteria [29].

\section{INT colorimetric assay for MIC and MBC determinations}

The MIC and MBC determinations on the tested bacteria were conducted using rapid $p$-iodonitrotetrazolium chloride (INT) colorimetric assay according to described methods [27] with some modifications [30-32].
To evaluate the antibiotic-potentiating effects, a preliminary study was carried out with 7 antibiotics (AMP, CEF, CHL, CIP, KAN, STR and TET) and samples from Nauclea pobeguinii (NPB, NPL, compounds 1-4) against one of the most probematic bacterial

Table $1 \mathrm{MIC}$ and $\mathrm{MBC}(\mu \mathrm{g} / \mathrm{mL})$ of Nauclea pobeguinii extracts and chloramphenicol on the panel of tested bacteria

\begin{tabular}{llll}
\hline $\begin{array}{l}\text { Bacterial } \\
\text { strains }\end{array}$ & \multicolumn{3}{l}{ Tested samples, MIC and MBC $(\mu \mathrm{g} / \mathrm{mL})$} \\
\cline { 2 - 4 } & NPB & NPL & $\mathrm{CHL}$ \\
\hline Escherichia coli & & & \\
ATCC8739 & $512(>1024)$ & $128(>1024)$ & $\mathbf{8}(256)$ \\
ATCC10536 & $\mathbf{3 2}(1024)$ & $256(>1024)$ & $16(32)$ \\
W 3110 & $1024(>1024)$ & $>1024$ & $64(128)$ \\
MC4100 & $256(>1024)$ & $256(>1024)$ & $128(128)$ \\
AG100 A & $1024(>1024)$ & $1024(>1024)$ & $64(64)$ \\
AG100Atet & $256(256)$ & $512(1024)$ & $64(128)$ \\
AG102 & $1024(>1024)$ & $512(>1024)$ & $64(64)$ \\
AG100 & $\mathbf{6 4}(256)$ & $512(>1024)$ & $16(64)$
\end{tabular}

Enterobacter aerogenes

$\begin{array}{llll}\text { ATCC13048 } & 1024(>1024) & 1024(>1024) & \mathbf{8}(32) \\ \text { EA294 } & 1024(>1024) & >1024 & 16(128) \\ \text { CM64 } & 1024(>1024) & >1024 & 128(>256) \\ \text { EA298 } & \mathbf{6 4}(1024) & 1024(1024) & 256(>256) \\ \text { EA27 } & 512(>1024) & 256(>1024) & >256 \\ \text { EA289 } & >1024 & 1024(>1024) & 256(>256) \\ \text { EA3 } & 512(>1024) & 1024(>1024) & >256\end{array}$

Klebsiella pneumoniae

$\begin{array}{llll}\text { ATCC11296 } & 256(>1024) & 256(>1024) & \mathbf{8}(256) \\ \text { KP55 } & 128(>1024) & 128(>1024) & 32(128) \\ \text { KP63 } & 1024(>1024) & 256(>1024) & 128(>256) \\ \text { K2 } & 512(>1024) & >1024 & 64(256) \\ \text { K24 } & 1024(>1024) & 512(>1024) & 32(256)\end{array}$

Pseudomonas aeruginosa

$\begin{array}{clll}\text { PA01 } & >1024 & 1024(>1024) & 128(>256) \\ \text { PA124 } & 1024(>1024) & >1024 & 256(>256) \\ \text { Providencia stuartii } & & & \\ \text { ATCC29916 } & 1024(>1024) & >1024 & 16(32) \\ \text { PS2636 } & 512(1024) & >1024 & 32(32) \\ \text { PS299645 } & 1024(>1024) & 512(1024) & 32(256) \\ \text { NEA16 } & 512(>1024) & 512(>1024) & 256(>256) \\ \text { Enterobacter cloacae } & & & \\ \text { BM47 } & 1024(>1024) & >1024 & 256(>256) \\ \text { ECCl69 } & 256(512) & 512(1024) & >256 \\ \text { BM67 } & >1024 & >1024 & 256(>256)\end{array}$

The Tested extract were obtained from the bark (NPB) and leaves (NPL); Values in bold; significant activity

CHL chloramphenicol, MIC Minimal Inhibitory Concentration, MBC Minimal Bactericidal Concentration 
strains, $P$. aeruginosa PA124 (see Additional file 1: Table S2 and S3). Results allowed selecting NPB, NPL and 4 and their antibiotic-potentiating effects were further evaluated. Hence, extracts (NPB and NPL) and compound 4 were tested in association with antibiotics at their sub-inhibitory concentrations ( $\mathrm{MIC} / 2$ and $\mathrm{MIC} / 4)$ as obtained in each bacterium $[9,11,13]$ respectively against 7 and 6 bacterial strains. Fractional inhibitory concentration (FIC) was calculated as the ratio of $\mathrm{MIC}_{\text {Antibiotic in combination }} / \mathrm{MIC}_{\text {Antibiotic alone }}$ and the results were discussed as follows: synergy $(\leq 0.5)$, indifferent $(>0.5$ to 4$)$, or antagonism $(>4)[33,34]$. All assays were performed in triplicate.

\section{Results}

Compounds tested in this study included 3-acetoxy11-oxo-urs-12-ene (1; purity: $90 \%), p$-coumaric acid (2; purity: $97 \%$ ), citric acid trimethyl ester (3; purity: $97 \%)$, resveratrol (4; purity: $98 \%)$, resveratrol $\beta_{-D^{-}}$ glucopyranoside (5; purity: $95 \%$ ), and strictosamide (6; purity: $96 \%$ ) previously isolated in the bark of Nauclea pobeguinii [25]. The antibacterial activity of these compounds as well as the crude extracts was evaluated in a panel of Gram-negative bacteria including MDR phenotypes. The results are summarized in Tables 1 and 2.

MIC results as compiled in Table 1 indicate that values ranging from $32-1024 \mu \mathrm{g} / \mathrm{mL}$ were obtained with $\mathrm{NPB}$ and NPL respectively on $26 / 29(89.7 \%)$ and 20/29 $(69.0 \%)$ of the tested bacterial strains. The lowest MIC value of $32 \mu \mathrm{g} / \mathrm{mL}$ was recorded with NPB against
Escherichia coli ATCC10536. Table 2 reports the MIC values of compounds from NPB. It's appears that $\mathbf{4}$ was active on all the ten selected bacteria including ATCC strains and clinical MDR phenotypes, whilst 1, 3 and 6 displayed poor and selective inhibitory effects. Compounds $\mathbf{2}$ and $\mathbf{5}$ were not active on all tested microorganisms. The lowest MIC value for compound $(16 \mu \mathrm{g} / \mathrm{mL})$ was obtained with $\mathbf{4}$ against Klebsiella pneumoniae KP55 strain. The best extract (NPB) as well as the most active compound (4) had low bactericidal activities, displaying MBC values only against 6/29 (20.7 \%) and 5/10 (50 \%) of the tested pathogens respectively.

Seven antibiotics used in bacterial chemotherapy were combined with NPB, NPL, compounds 1-4 and tested in a preliminary study against the problematic nosocomial pathogen, $P$. aeruginosa PA124. The results (Additional file 1: Table S2 and S3) indicated that there was no improvement of the activity of the two beta-lactamines tested (CEF and AMP). Consequently, CEF and AMP as well as compounds 1-3 having low antibiotic-potentiating activity against PA124 were not further investigated. Five antibiotics (CIP, TET, KAN, STR and CHL) were combined with NPB, NPL and compound 4 at their MIC/2 and $\mathrm{MIC} / 5$, as obtained on each of the tested bacterial strains (Tables 3 and 4). At MIC/2 of the samples, NPB and $4(6 / 6)$ had synergistic effects with CHL and KAN on $100 \%$ tested MDR bacteria. At MIC/4, $100 \%$ synergistic effects were also obtained when NPB was combined with STR (Table 3) and when $\mathbf{4}$ was associated with STR and CIP (Table 4). NPL had lower synergistic effects with antibiotic at MIC/2 and MIC/4.

Table 2 MICs and MBCs $(\mu \mathrm{g} / \mathrm{mL})$ of compounds from Nauclea pobeguinii against selected bacterial strains

\begin{tabular}{|c|c|c|c|c|c|c|}
\hline \multirow[t]{2}{*}{ Bacterial strains } & \multicolumn{6}{|c|}{ Compounds, MIC and MBC (in bracket) } \\
\hline & 1 & 2 & 3 & 4 & 5 & 6 \\
\hline \multicolumn{7}{|l|}{ Escherichia coli } \\
\hline ATCC8739 & $256(>256)$ & $>256$ & $>256$ & $64(64)$ & $>256$ & $>256$ \\
\hline AG100Atet & $>256$ & $>256$ & $>256$ & $128(256)$ & $>256$ & $>256$ \\
\hline AG102 & $>256$ & $>256$ & $1024(>256)$ & $32(32)$ & $>256$ & $>256$ \\
\hline \multicolumn{7}{|c|}{ Enterobacter aerogenes } \\
\hline CM64 & $>256$ & $>256$ & $>256$ & $64(>256)$ & $>256$ & $>256$ \\
\hline \multicolumn{7}{|c|}{ Klebsiella pneumoniae } \\
\hline ATCC11296 & $>256$ & $>256$ & $>256$ & $64(>256)$ & $>256$ & $>256$ \\
\hline KP55 & $>256$ & $>256$ & $32(128)$ & $16(32)$ & $>256$ & $256(>256)$ \\
\hline \multicolumn{7}{|c|}{ Pseudomonas aeruginosa } \\
\hline PA01 & $>256$ & $>256$ & $>256$ & $64(128)$ & $>256$ & $256(>256)$ \\
\hline PA124 & $>256$ & $>256$ & $>256$ & $256(>256)$ & $>256$ & $>256$ \\
\hline \multicolumn{7}{|c|}{ Providencia stuartii } \\
\hline ATCC29916 & $>256$ & $>256$ & $>256$ & $128(>256)$ & $>256$ & $>256$ \\
\hline PS2636 & $>256$ & $>256$ & $>256$ & $256(>256)$ & $>256$ & $>256$ \\
\hline
\end{tabular}

1: 3-acetoxy-11-oxo-urs-12-ene; 2: -coumaric acid; 3: citric acid trimethyl ester ; 4: resveratrol; 5: resveratrol $\beta$-o-glucopyranoside; 6: strictosamide 
Table 3 MIC of antibiotics in association of bark and leaves extracts of Nauclea pobeguinii at MIC/2 and MIC/4 against selected MDR bacteria

\begin{tabular}{|c|c|c|c|c|c|c|c|c|c|c|}
\hline \multirow[t]{2}{*}{ Antibiotics $^{a}$} & \multirow{2}{*}{\multicolumn{2}{|c|}{$\begin{array}{l}\text { Extract and } \\
\text { concentration }\end{array}$}} & \multicolumn{7}{|c|}{$\begin{array}{l}\text { Bacterial strains }{ }^{\mathrm{b}}, \mathrm{MIC}(\mu \mathrm{g} / \mathrm{mL}) \text { of antibiotics in the absence and presence of the extract and FIC } \\
\text { (in brackets) }\end{array}$} & \multirow[t]{2}{*}{ PBSS (\%) } \\
\hline & & & PA124 & CM64 & NAE16 & BM47 & KP55 & KP63 & AG100Atet & \\
\hline \multirow[t]{5}{*}{$\mathrm{CHL}$} & & 0 & 256 & 128 & 256 & 256 & 32 & 128 & 64 & \\
\hline & B & $\mathrm{MIC} / 2$ & $128(0.5) S$ & $64(0.5) S$ & $32(0.125) \mathrm{S}$ & $16(0.06) \mathrm{S}$ & $16(0.5) \mathrm{S}$ & $8(0.06) S$ & $32(0.5) S$ & $7 / 7(100 \%)$ \\
\hline & & $\mathrm{MIC} / 4$ & $128(0.5) S$ & $64(0.5) S$ & $32(0.13) \mathrm{S}$ & $16(0.06) \mathrm{S}$ & $32(1) \mid$ & $8(0.06) S$ & $32(0.5) S$ & $6 / 7(85.7 \%)$ \\
\hline & L & $\mathrm{MIC} / 2$ & $256(1) \mid$ & $128(1) \mid$ & $16(0.06) \mathrm{S}$ & $32(0.13) \mathrm{S}$ & $32(1) \mid$ & $8(0.06) \mathrm{S}$ & $16(0.25) \mathrm{S}$ & $4 / 7(57.1)$ \\
\hline & & $\mathrm{MIC} / 4$ & $256(1) \mid$ & $128(1) \mid$ & $16(0.06) \mathrm{S}$ & $64(0.25) \mathrm{S}$ & $32(1) \mid$ & $8(0.06) \mathrm{S}$ & $16(0.25) \mathrm{S}$ & 4/7 (57.1) \\
\hline \multirow[t]{5}{*}{ KAN } & & 0 & 128 & 64 & 64 & 32 & 64 & 64 & 32 & \\
\hline & B & $\mathrm{MIC} / 2$ & $64(0.5) S$ & $4(0.06) \mathrm{S}$ & $8(0.13) S$ & $4(0.13) S$ & $32(0.5) \mathrm{S}$ & $8(0.13) S$ & $16(0.5) S$ & $7 / 7(100 \%)$ \\
\hline & & $\mathrm{MIC} / 4$ & $64(0.5) S$ & $4(0.06) S$ & $8(0.13) S$ & $4(0.13) S$ & $32(0.5) S$ & $8(0.13) S$ & $16(0.5) S$ & $7 / 7(100 \%)$ \\
\hline & L & $\mathrm{MIC} / 2$ & $64(0.5) S$ & $4(0.06) \mathrm{S}$ & $8(0.13) S$ & $4(0.13) S$ & $64(1) \mid$ & $16(0.25) \mathrm{S}$ & $16(0.5) S$ & 6/7 (85.7 \%) \\
\hline & & $\mathrm{MIC} / 4$ & $64(0.5) S$ & $4(0.06) S$ & $8(0.13) S$ & $4(0.13) S$ & $64(1) \mid$ & $16(0.25) \mathrm{S}$ & $16(0.5) S$ & $6 / 7(85.7 \%)$ \\
\hline \multirow[t]{5}{*}{ STR } & & 0 & 64 & 64 & 32 & 16 & 64 & 16 & 128 & \\
\hline & B & $\mathrm{MIC} / 2$ & $64(1) \mid$ & $4(0.06) S$ & $16(0.5) S$ & $4(0.25) S$ & $32(0.5) S$ & $2(0.13) S$ & $-(\geq 2) n a$ & $5 / 6(83.3 \%)$ \\
\hline & & $\mathrm{MIC} / 4$ & $256(4) A$ & $4(0.06) S$ & $16(0.5) S$ & $4(0.25) S$ & $32(0.5) S$ & $8(0.5) \mathrm{S}$ & $-(\geq 2) n a$ & $5 / 6(83.3 \%)$ \\
\hline & $L$ & $\mathrm{MIC} / 2$ & $256(4) A$ & $2(0.03) S$ & $8(0.25) S$ & $2(0.13) S$ & $16(0.25) S$ & $4(0.25) S$ & $128(1) \mid$ & $5 / 7(71.4 \%)$ \\
\hline & & $\mathrm{MIC} / 4$ & $256(4) A$ & $4(0.06) \mathrm{S}$ & $16(0.5) S$ & $4(0.25) S$ & $64(1) \mid$ & $4(0.25) S$ & $-(\geq 2) n a$ & $4 / 6(66.7 \%)$ \\
\hline \multirow[t]{5}{*}{ CIP } & & 0 & 64 & 16 & 8 & 16 & 16 & 8 & 64 & \\
\hline & B & $\mathrm{MIC} / 2$ & $32(0.5) \mathrm{S}$ & $64(4) A$ & $8(1) \mid$ & $8(0.5) \mathrm{S}$ & $16(1) \mid$ & $4(0.5) S$ & $64(1) \mid$ & $3 / 7(42.9 \%)$ \\
\hline & & $\mathrm{MIC} / 4$ & $32(0.5) \mathrm{S}$ & $64(4) A$ & $8(1) \mid$ & $16(1) \mid$ & $32(2) A$ & $8(1) \mid$ & $64(1) \mid$ & 1/7 (14.3 \%) \\
\hline & L & $\mathrm{MIC} / 2$ & $64(1) \mid$ & $64(4) A$ & $16(2) A$ & $16(1) \mid$ & $16(1) \mid$ & $4(0.5) S$ & $64(1) \mid$ & 1/7 (14.3 \%) \\
\hline & & $\mathrm{MIC} / 4$ & $64(1) \mid$ & $64(4) A$ & $16(2) A$ & $16(1) \mid$ & $16(1) \mid$ & $4(0.5) S$ & $64(1) \mid$ & $1 / 7(14.3 \%)$ \\
\hline \multirow[t]{5}{*}{ TET } & & 0 & 64 & 64 & 128 & 32 & 32 & 64 & 256 & \\
\hline & B & $\mathrm{MIC} / 2$ & $32(0.5) S$ & $4(0.06) S$ & $32(0.25) \mathrm{S}$ & $16(0.5) S$ & $64(2) \mid$ & $32(0.5) S$ & $4(0.02) S$ & $6 / 7(85.7 \%)$ \\
\hline & & $\mathrm{MIC} / 4$ & $32(0.5) \mathrm{S}$ & $2(0.03) S$ & $32(0.25) \mathrm{S}$ & $16(0.5) S$ & $64(2) \mid$ & $64(1) \mid$ & $4(0.02) S$ & $5 / 7(71.4 \%)$ \\
\hline & $L$ & $\mathrm{MIC} / 2$ & $64(1) \mid$ & $2(0.03) S$ & $128(1) \mid$ & $32(1) \mid$ & $-(\geq 8) A$ & $64(1) \mid$ & $4(0.02) S$ & 2/7 (28.6 \%) \\
\hline & & $\mathrm{MIC} / 4$ & $64(1) \mid$ & $2(0.03) S$ & $128(1) \mid$ & $32(1) \mid$ & $-(\geq 8) A$ & $64(1) \mid$ & $4(0.02) S$ & 2/7 (28.6 \%) \\
\hline
\end{tabular}

$(-)$ : $>256 \mu \mathrm{g} / \mathrm{mL} ; 0$ : no extract (only antibiotic tested); na: non-applicable; Values in bold: MIC of antibiotic alone and significant synergistic effects $S$ Synergy; I Indifference, $A$ Antagonism, $B$ bark extract, $L$ Leaves extract, FIC fractional inhibitory concentration

${ }^{a}$ Antibiotics [CHL: chloramphenicol, AMP : ampicillin, CEF: cefepime, KAN : kanamycin, STR: streptomycin, CIP : ciprofloxacin, TET : tetracycline]

${ }^{b}$ Bacterial strains: Escherichia coli [ AG100Atet], Pseudomonas aeruginosa [PA124], Enterobacter aerogenes [CM64], Enterobacter cloacae [BM47], Klebsiella pneumoniae [KP55, KP63], Providencia stuartii [NAE16]

CPBSS: percentage of bacteria strain on which synergism has been observed; (): fold increase in MIC values of the antibiotics after association with plants extract

\section{Discussion}

MDR resistant bacteria of the family enterobacteriaceae or as well as the nosocomial pathogen Pseudomonas aeruginosa are largely involved clinically in treatment failures [35]. Clinical bacteria used in the present study actively express efflux pumps $[5,9,35,36]$ and therefore represent good models in the search of chemicals to combat drug resistance. Phytochemicals are routinely classified as significantly active antibacterial agents on the basis of their MIC values below $100 \mu \mathrm{g} / \mathrm{mL}$ for crude extracts or $10 \mu \mathrm{g} / \mathrm{mL}$ for compounds; the activity is considered moderate when $100<\mathrm{MIC}<625 \mu \mathrm{g} / \mathrm{mL}$ (crude extracts) or $10<\mathrm{MIC}<100 \mu \mathrm{g} / \mathrm{mL}$ for molecules [37-39].
Taking in account these cutoff points, it can be deduced that NPB had a good antibacterial potential, as MIC values below $100 \mu \mathrm{g} / \mathrm{mL}$ were obtained with this extract against E. coli ATCC10536, AG100 and Enterobacter aerogenes CM64 strains. In addition, the MIC value of $64 \mu \mathrm{g} / \mathrm{mL}$ obtained with NPB against E. aerogenes EA298 strain was lower than that of the reference drug CHL $(256 \mu \mathrm{g} / \mathrm{mL})$. Nonetheless, compounds 1-6 (from NPB) rather had moderate, low or no inhibitory effects, suggesting that they may act synergistically in NPB. However, the lowest MIC value of $16 \mu \mathrm{g} / \mathrm{mL}$ obtained with 4 was better than that of CHL $(32 \mu \mathrm{g} / \mathrm{mL})$ against $K$. pneumoniae KP55 strain, also highlighting the possible usefulness of this 
Table 4 MIC of antibiotics after the association of resveratrol (4) at MIC/2 and MIC/4 against selected MDR bacteria

\begin{tabular}{|c|c|c|c|c|c|c|c|c|}
\hline \multirow[t]{2}{*}{ Antibiotics $^{a}$} & \multirow{2}{*}{$\begin{array}{l}\text { Concentration } \\
\text { of } 4\end{array}$} & \multicolumn{6}{|c|}{ Bacteria strains ${ }^{\mathrm{b}}$, MIC of antibiotics alone and in presence of 4 (Resveratrol), FIC (in bracket ) } & \multirow[t]{2}{*}{ PBSS $(\%)^{c}$} \\
\hline & & PA124 & CM64 & KP55 & AG102 & AG100Atet & PS2636 & \\
\hline \multirow[t]{3}{*}{$\overline{\mathrm{CHL}}$} & 0 & 256 & 128 & 32 & 64 & 64 & 256 & \\
\hline & $\mathrm{MIC} / 2$ & $32(0.25) S$ & $2(0.02) S$ & $16(0.5) \mathrm{S}$ & $64(1) \mid$ & $<2(<0.03) S$ & $64(0.25) \mathrm{S}$ & $5 / 6(83.3 \%)$ \\
\hline & $\mathrm{MIC} / 4$ & $32(0.25) S$ & $4(0.03) S$ & $16(0.5) S$ & $64(1) \mid$ & $<2(<0.03) S$ & $64(0.25) \mathrm{S}$ & $5 / 6(83.3 \%)$ \\
\hline \multirow[t]{3}{*}{ KAN } & 0 & 128 & 64 & 64 & 4 & 32 & 4 & \\
\hline & $\mathrm{MIC} / 2$ & $64(0.5) S$ & $<2(<0.03) S$ & $32(0.5) \mathrm{S}$ & $<2(<0.5) S$ & $<2(0.06) S$ & $4(1) \mid$ & $5 / 6(83.3 \%)$ \\
\hline & $\mathrm{MIC} / 4$ & $64(0.5) S$ & $<2(<0.03) \mathrm{S}$ & $32(0.5) S$ & $<2(<0.5) S$ & $<2(0.06) \mathrm{S}$ & $4(1) \mid$ & $5 / 6(83.3 \%)$ \\
\hline \multirow[t]{3}{*}{ STR } & 0 & 64 & 128 & 64 & $\leq 2$ & - & $\leq 2$ & \\
\hline & $\mathrm{MIC} / 2$ & $32(0.5) S$ & $64(0.5) S$ & $16(0.25) S$ & $<2$ na & $64(\leq 0.5) \mathrm{S}$ & $<2$ na & $4 / 4$ (100 \%) \\
\hline & $\mathrm{MIC} / 4$ & $32(0.5) S$ & $64(0.5) S$ & $32(0.5) \mathrm{S}$ & $4(>2)$ na & $128(\leq 0.5) S$ & $<2$ na & $4 / 4(100 \%)$ \\
\hline \multirow[t]{3}{*}{ CIP } & 0 & 64 & 8 & 4 & 1 & 64 & 4 & \\
\hline & $\mathrm{MIC} / 2$ & $4(0.06) S$ & $<\mathbf{2}(0.25) \mathrm{S}$ & $<\mathbf{2}(<0.5) S$ & $<0.5(<0.5) S$ & $<2(<0.03) S$ & $8(2) \mid$ & $5 / 6(83.3 \%)$ \\
\hline & $\mathrm{MIC} / 4$ & $16(0.25) S$ & $<\mathbf{2}(0.25) S$ & $<\mathbf{2}(<0.5) S$ & $<0.5(<0.5) S$ & $<2(<0.03) S$ & $<0.5(<0.13) S$ & 6/6 (100 \%) \\
\hline \multirow[t]{3}{*}{ TET } & 0 & 64 & 64 & 32 & 4 & 256 & 64 & \\
\hline & $\mathrm{MIC} / 2$ & $4(0.06) S$ & $64(1) \mid$ & $32(1) \mid$ & $<\boldsymbol{2}(<0.5) S$ & $256(1) \mid$ & $32(0.5) S$ & $3 / 6(50 \%)$ \\
\hline & $\mathrm{MIC} / 4$ & $4(0.06) S$ & $128(2) \mid$ & $16(0.5) S$ & $<2(<0.5) S$ & $256(1) \mid$ & $16(0.25) \mathrm{S}$ & 4/6 (66.7 \%) \\
\hline
\end{tabular}

$(-)$ : $>256 \mu \mathrm{g} / \mathrm{mL}$; 0: without compound 4 (only antibiotic tested). CIP have been tested at $64 \mu \mathrm{g} / \mathrm{ml}$ on AG102 and PS2636; na: non-applicable; Values in bold: MIC of antibiotic alone or significant synergistic effects

$S$ Synergy, I Indifference, A Antagonism, $P$ product, FIC fractional inhibitory concentration

${ }^{a}$ Antibiotics [CHL: chloramphenicol, KAN : kanamycin, STR: streptomycin, CIP : ciprofloxacin, TET : tetracycline]

bBacterial strains: Escherichia coli [ AG102, AG100Atet], Pseudomonas aeruginosa [PA124], Enterobacter aerogenes [CM64], Klebsiella pneumoniae [KP55], Providencia stuartii [PS2636]

'PBSS: percentage of bacteria strain on which synergism has been observed

compound in the fight against MDR bacteria. It is worth noting that compound 5 (a glucoside of $\mathbf{4}$ ) was not active contrary to its aglycon $\mathbf{4}$, indicating that the presence of glucose in compound $\mathbf{5}$ significantly reduces its antibacterial activities.

Reversal of multi-drug resistance appears today as another attempt to mitigate the spread of resistance in bacteria. In recent years, many botanicals showed antibiotic-modulation effect in efflux pumps overexpressing MDR bacteria [9, 10, 16, 19, 20, 40-42]. In the present study, we observed that a beneficial effects of the combination of NPB with CHL, KAN as well as that of compound $\mathbf{4}$ with STR and CIP in all tested bacteria were achieved. Synergistic or modulating effects of NPB and 4 with other antibiotics were noted on more than $70 \%$ of the tested MDR bacteria in several case (Tables 3 and 4), suggesting that they can act as efflux pump inhibitors [40]. This is strenghten by the fact that no synergistic effect was obtained with beta-lactamines (CEF and AMP) in the preliminary test (Additional file 1: Tables S2 and S3), as their target are located in the bacterial coat and hence, are not generally affected by AcrAB-TolC and MexAB-OprM efflux pumps in Enterobacteriaceae and $P$. aeruginosa respectively [4].

This is the first time to report the potential of NPB to prevent the proliferation of MDR Gram-negative bacterial as well as to reverse antibiotic resistance in MDR bacteria. However, the methanol extract from roots of Nauclea pobeguinii showed synergistic effects with ampicillin and amoxicillin against Staphylococcus aureus and drug-sensitive Klebsiella pneumoniae [43]. The present study therefore provides additional information on the ability of other parts of Nauclea pobeguinii to potentiate the activity of antibiotics. Though, the antibacterial potential of compound $\mathbf{4}$ is well known [44], the present study also identify this stilbene as the potent antibacterial constituent of Nauclea pobeguiinii. This study also provides more information on its inhibitory potential against MDR bacteria expressing active efflux pumps as well as it ability to potentiate the activity of antibiotics.

\section{Conclusion}

The results reported herein are very interesting, in regards to the medical importance of the studied microorganisms. These data provide evidence that crude extracts and compounds from Nauclea pobeguinii and mostly the bark extract (NPB) and compound $\mathbf{4}$ are potential sources of compounds to fight MDR bacterial species. The bark extract and $\mathbf{4}$ could also be used in combination with antibiotics to overcome bacterial resistance. 


\section{Additional file}

Additional file 1: Table S1. Bacterial strains used and their features. Table S2. Preliminary assay of extracts from bark and leaves of Nauclea pobeguinii in combination with commonly used antibiotics against PA124. Table S3. Preliminary assay with compounds in combination with commonly used antibiotics against PA124. (DOC $173 \mathrm{~kb}$ )

\section{Abbreviations}

1, 3-acetoxy-11-oxo-urs-12-ene; 2 , $p$-coumaric acid; 3 , citric acid trimethyl ester; 3, resveratrol; 4, resveratrol $\beta$-D-glucopyranoside; 6 , strictosamide; AMP, ampicillin; ATCC, American Type Culture Collection; CEF, cefepime; CHL, chloramphenicol; CIP, ciprofloxacin; EPI, efflux pump inhibitors; FIC, fractional inhibitory concentration; HNC, National Herbarium of Cameroon; INT, p-iodonitrotetrazolium chloride; KAN, kanamycin; MBC, minimal bactericidal concentrations; MDR, multidrug resistant; MDRGN, multidrug resistant Gram-negative; $\mathrm{MeOH}$, methanol; $\mathrm{MIC}$, minimal inhibitory concentrations; NPB, Nauclea pobeguiinii bark; NPL, Nauclea pobeguiinii leaves; RA, reference antibiotics; RND, resistance-nodulation-cell division; STR, streptomycin; TET, Tetracycline.

\section{Acknowledgements}

Authors are thankful to the Cameroon National Herbarium (Yaounde) for the plant identification. Authors are also thankful to UMR-MD1 (Mediterranean University, Marseille, France) for providing some clinical bacteria.

\section{Funding}

No funding.

\section{Availability of data and materials}

The datasets supporting the conclusions of this article are presented in this main paper. Plant materials used in this study have been identified at the Cameroon National Herbarium where voucher specimens are deposited.

\section{Authors' contributions}

AJS and LPS carried out the study; VK designed the experiments and wrote the manuscript; VK and BTN supervised the work; VK provided the bacterial strains; all authors read and approved the final manuscript.

\section{Competing interests}

The authors declare that they have no competing interests.

\section{Consent for publication}

Not applicable in this section.

\section{Ethic approval and consent to participate}

Not applicable in this section.

\section{Author details}

${ }^{1}$ Department of Biochemistry, Faculty of Science, University of Dschang, Dschang, Cameroon. ${ }^{2}$ Department of Pharmaceutical Sciences, CCS, Federal University of Santa Catarina, Florianópolis 88040-900, SC, Brazil. ${ }^{3}$ Department of Organic Chemistry, Faculty of Science, University of Yaoundé 1, Yaoundé, Cameroon.

Received: 25 February 2016 Accepted: 22 June 2016

Published online: 07 July 2016

\section{References}

1. Pages JM, Amaral L. Mechanisms of drug efflux and strategies to combat them: challenging the efflux pump of Gram-negative bacteria. Biochim Biophys Acta. 2009;1794(5):826-33.

2. Lomovskaya O, Bostian KA. Practical applications and feasibility of efflux pump inhibitors in the clinic-a vision for applied use. Biochem Pharmacol. 2006;71(7):910-8.

3. Gangoue-Pieboji J, Bedenic B, Koulla-Shiro S, Randegger C, Adiogo D, Ngassam P, Ndumbe P, Hachler H. Extended-spectrum-beta-lactamaseproducing enterobacteriaceae in Yaounde, Cameroon. J Clin Microbiol. 2005;43(7):3273-7.
4. Kuete V, Alibert-Franco S, Eyong KO, Ngameni B, Folefoc GN, Nguemeving JR, Tangmouo JG, Fotso GW, Komguem J, Ouahouo BM, et al. Antibacteria activity of some natural products against bacteria expressing a multidrugresistant phenotype. Int J Antimicrob Agents. 2011;37(2):156-61.

5. Ghisalberti D, Masi M, Pages JM, Chevalier J. Chloramphenicol and expression of multidrug efflux pump in Enterobacter aerogenes. Biochem Biophys Res Commun. 2005;328(4):1113-8.

6. Cowan MM. Plant products as antimicrobial agents. Clin Microbiol Rev. 1999;12(4):564-82.

7. Kuete V. Medicinal Plant Research in Africa. In: Kuete V, editor. Pharmacology and Chemistry. 1st ed. Oxford: Elsevier; 2013.

8. Kuete $V$, Efferth T. African flora has the potential to fight multidrug resistance of cancer. BioMed Res Int. 2015;2015:914813.

9. Fankam AG, Kuete V, Voukeng IK, Kuiate JR, Pages JM. Antibacterial activities of selected Cameroonian spices and their synergistic effects with antibiotics against multidrug-resistant phenotypes. BMC Complement Altern Med. 2011;11:104.

10. Fankam AG, Kuiate JR, Kuete V. Antibacterial and antibiotic resistance modifying activity of the extracts from allanblackia gabonensis, combretum molle and gladiolus quartinianus against Gram-negative bacteria including multi-drug resistant phenotypes. BMC Complement Altern Med. 2015;15:206

11. Noumedem JA, Mihasan M, Kuiate JR, Stefan M, Cojocaru D, Dzoyem JP, Kuete V. In vitro antibacterial and antibiotic-potentiation activities of four edible plants against multidrug-resistant Gram-negative species. BMC Complement Altern Med. 2013:13:190.

12. Tankeo SB, Tane $P$, Kuete $V$. In vitro antibacterial and antibiotic-potentiation activities of the methanol extracts from Beilschmiedia acuta, Clausena anisata, Newbouldia laevis and Polyscias fulva against multidrug-resistant Gram-negative bacteria. BMC Complement Altern Med. 2015;15(1):412.

13. Voukeng IK, Kuete V, Dzoyem JP, Fankam AG, Noumedem JA, Kuiate JR, Pages JM. Antibacterial and antibiotic-potentiation activities of the methanol extract of some cameroonian spices against Gram-negative multidrug resistant phenotypes. BMC Res Notes. 2012;5:299.

14. Seukep JA, Sandjo LP, Ngadjui BT, Kuete V. Antibacterial activities of the methanol extracts and compounds from Uapaca togoensis against Gramnegative multi-drug resistant phenotypes. S Afr J Bot. 2016;103:1-5.

15. Djeussi DE, Sandjo LP, Noumedem JA, Omosa LK BTN, Kuete V. Antibacterial activities of the methanol extracts and compounds from Erythrina sigmoidea against Gram-negative multi-drug resistant phenotypes. BMC Complement Altern Med. 2015;15(1):453.

16. Stermitz FR, Lorenz P, Tawara JN, Zenewicz LA, Lewis K. Synergy in a medicinal plant: antimicrobial action of berberine potentiated by $5^{\prime}$ methoxyhydnocarpin, a multidrug pump inhibitor. Proc Natl Acad Sci U S A 2000;97(4):1433-7

17. Nikaido H, Pages JM. Broad-specificity efflux pumps and their role in multidrug resistance of Gram-negative bacteria. FEMS Microbiol Rev. 2012;36(2):340-63.

18. Lomovskaya O, Watkins W. Inhibition of efflux pumps as a novel approach to combat drug resistance in bacteria. J Mol Microbiol Biotechnol. 2001;3(2):225-36.

19. Gibbons S. Plants as a source of bacterial resistance modulators and antiInfective agents. Phytochem Rev. 2005;4:63-78.

20. Bama SS, Kingsley SJ, Anan S, Bama P. Antibacterial activity of different phytochemical extracts from the leaves of T. procumbens: Identification and mode of action of the terpeniod compounds as antibacterials. Int J Pharm Pharmaceut Sci. 2012:4:557-64.

21. Fankam AG, Kuiate JR, Kuete V. Antibacterial activities of Beilschmiedia obscura and six other Cameroonian medicinal plants against multi-drug resistant Gram-negative phenotypes. BMC Complement Altern Med. 2014;14:241.

22. Karou SD, Tchacondo T, Illboudo DP, Simpore J. Sub-Saharan Rubiaceae: a review of their traditional uses, phytochemistry and biological activities. Pak J Biol Sci. 2011;14(3):149-69.

23. Kadiri H, Adegor E, Asagba S. Effect of aqueous Nauclea pobeguinii leaf extract on rats induced with hepatic injury. Res J Med Plant. 2007;1(4):139-43.

24. Mesia GK, Tona GL, Penge O, Lusakibanza M, Nanga TM, Cimanga RK, Apers S, Van Miert S, Totte J, Pieters L, et al. Antimalarial activities and toxicities of three plants used as traditional remedies for malaria in the Democratic Republic of Congo: Croton mubango, Nauclea pobeguinii and Pyrenacantha staudtii. Ann Trop Med Parasitol. 2005;99(4):345-57. 
25. Kuete V, Sandjo LP, Mbaveng AT, Seukep JA, Ngadjui BT, Efferth T. Cytotoxicity of selected Cameroonian medicinal plants and Nauclea pobeguinii towards multi-factorial drug-resistant cancer cells. BMC Complement Altern Med. 2015;15:309.

26. Mesia K, Tona L, Mampunza MM, Ntamabyaliro N, Muanda T, Muyembe T, Musuamba T, Mets T, Cimanga K, Totte J, et al. Antimalarial efficacy of a quantified extract of Nauclea pobeguinii stem bark in human adult volunteers with diagnosed uncomplicated falciparum malaria. Part 2: a clinical phase IIB trial. Planta Med. 2012;78(9):853-60.

27. Eloff JN. A sensitive and quick microplate method to determine the minimal inhibitory concentration of plant extracts for bacteria. Planta Med. 1998;64(8):711-3.

28. Mativandlela SPN, Lall N, Meyer JJM. Antibacterial, antifungal and antitubercular activity of (the roots of) Pelargonium reniforme (CURT) and Pelargonium sidoides (DC) (Geraniaceae) root extracts. S Afr J Bot. 2006; $72(2): 232-7$.

29. Kuete V, Kamga J, Sandjo LP, Ngameni B, Poumale HM, Ambassa P, Ngadjui BT. Antimicrobial activities of the methanol extract, fractions and compounds from Ficus polita Vahl. (Moraceae). BMC Complement Altern Med. 2011;11:6.

30. Kuete V, Nana F, Ngameni B, Mbaveng AT, Keumedjio F, Ngadjui BT. Antimicrobial activity of the crude extract, fractions and compounds from stem bark of Ficus ovata (Moraceae). J Ethnopharmacol. 2009;124(3):556-61.

31. Kuete V, Wansi JD, Mbaveng AT, Kana Sop MM, Tadjong AT, Beng VP, Etoa FX, Wandji J, Meyer JJM, Lall N. Antimicrobial activity of the methanolic extract and compounds from Teclea afzelii (Rutaceae). S Afr J Bot. 2008; $74(4): 572-6$.

32. Djeussi DE, Noumedem JA, Seukep JA, Fankam AG, Voukeng IK, Tankeo SB, Nkuete AH, Kuete V. Antibacterial activities of selected edible plants extracts against multidrug-resistant Gram-negative bacteria. BMC Complement Altern Med. 2013;13(1):164

33. Shahverdi AR, Monsef-Esfahani HR, Tavasoli F, Zaheri A, Mirjani R. TransCinnamaldehyde from Cinnamomum zeylanicum Bark Essential Oil Reduces the Clindamycin Resistance of Clostridium difficile in vitro. J Food Sci. 2007;72(1):S055-8.

34. Noumedem JA, Mihasan M, Lacmata ST, Stefan M, Kuiate JR, Kuete V. Antibacterial activities of the methanol extracts of ten Cameroonian vegetables against Gram-negative multidrug-resistant bacteria. BMC Complement Altern Med. 2013;13:26.

35. Kuete V, Ngameni B, Tangmouo JG, Bolla JM, Alibert-Franco S, Ngadjui BT, Pages JM. Efflux pumps are involved in the defense of Gram-negative bacteria against the natural products isobavachalcone and diospyrone. Antimicrob Agents Chemother. 2010;54(5):1749-52.

36. Chevalier J, Pages JM, Eyraud A, Mallea M. Membrane permeability modifications are involved in antibiotic resistance in Klebsiella pneumoniae Biochem Biophys Res Commun. 2000;274(2):496-9.

37. Kuete V. Potential of Cameroonian plants and derived products against microbial infections: a review. Planta Med. 2010;76(14):1479-91.

38. Kuete V, Efferth T. Cameroonian medicinal plants: pharmacology and derived natural products. Front Pharmacol. 2010;1:123.

39. McGaw L, Lall N, Meyer JJ, Eloff JN. The potential of South African plants against Mycobacterium infections. J Ethnopharmacol. 2008;119(3):482-500.

40. Braga LC, Leite AA, Xavier KG, Takahashi JA, Bemquerer MP, Chartone-Souza E, Nascimento AM. Synergic interaction between pomegranate extract and antibiotics against Staphylococcus aureus. Can J Microbiol. 2005;51(7):541-7.

41. Tankeo SB, Lacmata ST, Noumedem JA, Dzoyem JP, Kuiate JR, Kuete V. Antibacterial and antibiotic-potentiation activities of some Cameroonian food plants against multi-drug resistant gram-negative bacteria. Chin J Integr Med. 2014;20(7):546-54.

42. Figueredo FG, Ferreira EO, Lucena BF, Torres CM, Lucetti DL, Lucetti EC, Silva JM, Santos FA, Medeiros CR, Oliveira GM, et al. Modulation of the antibiotic activity by extracts from Amburana cearensis A. C. Smith and Anadenanthera macrocarpa (Benth.) Brenan. Biomed Res Int. 2013;2013:640682.

43. Njimoh DL, Assob JC, Mokake SE, Nyhalah DJ, Yinda CK, Sandjon B. Antimicrobial activities of a plethora of medicinal plant extracts and hydrolates against human pathogens and their potential to reverse antibiotic resistance. Int J Microbiol. 2015;2015:547156.

44. Yang T, Wang L, Zhu M, Zhang L, Yan L. Properties and molecular mechanisms of resveratrol: a review. Pharmazie. 2015;70(8):501-6. 